\title{
Differential Effects of Acute and Chronic Exercise on Autophagy-related Gene Expression in Drosophila melanogaster
}

\author{
Hee Yeon Kim, Hye Jin Kim, Ji Sun Hwang and Won Jun Lee* \\ Department of Exercise Science, College of Health Sciences, Ewha Womans University, Seoul 120-750, Korea \\ Received August 20, 2014 /Revised September 18, 2014 /Accepted October 7, 2014
}

\begin{abstract}
Autophagy, the lysosomal degradation pathway, is an intracellular recycling system that is necessary for the metabolic benefits of exercise and for producing lasting beneficial effects of exercise in various diseases. However, the most recent studies have only examined the effect of a single bout of exercise or resistance exercise on autophagic responses. To determine the differential effects of acute and chronic exercise on the expression of autophagy-related genes in D. melanogaster, white-eyed mutant D. melanogaster were assigned randomly to four groups: control, acute exercise, $2 \mathrm{hr}$ chronic exercise, and $3 \mathrm{hr}$ chronic exercise. The flies were exercised using a mechanized platform known as the Power Tower. Our results revealed that a single bout of exercise resulted in increased mRNA levels of the Atg8a gene $(\sim 20 \%, p<0.05)$. However, Atg1 and Atg6 mRNA expression were not induced by acute exercise. Transcript levels of Atg6 $(\sim 29 \%, p<0.05)$ related to the nucleation of autophagosomes were significantly induced by $2 \mathrm{hr}$ of chronic exercise. However, this chronic exercise was not enough to increase Atg1 and Atg8a mRNA expression. On the other hand, $3 \mathrm{hr}$ of exercise for 7 days significantly increased Atg1, Atg6, and Atg8a gene expression-about 57\%, 37\%, and 71\%, respectively $(p<0.05)$. These results suggest that a single bout of exercise is not enough to induce full activation of selected autophagy-related genes in D. melanogaster. Our results demonstrated that chronic regular exercise induced autophagy-related gene expression, suggesting that chronic regular exercise training might be required to activate autophagic responses important for producing beneficial effects of exercise in various diseases.
\end{abstract}

Key words : Acute exercise, Autophagy-related 1 (Atg1), Autophagy-related 6 (Atg6), Autophagyrelated 8a (Atg8a), chronic exercise

\section{서 론}

지난 수년간 운동이 신체의 건강에 미치는 긍정적 요소들에 관한 다양한 연구들이 많이 이루어져왔다. 규칙적인 운동은 근육 부피 유지 및 강화, 적정 체중 유지에 필수적인 역할을 함에 따라 다양한 대사증후군(metabolic syndrome)의 예방 및 치료, 암, 그리고 알츠하이머와 같은 신경계 질환을 예방하는 데 중요한 인자로 인식되어왔다[3,5]. 이러한 운동의 효과에 대해 많은 연구자들이 관심을 가지게 되면서, 사람을 비롯한 다양한 동물 모델과 세포수준에 이르기까지 운동이 어떻게 질병을 예방하고 개선시키는지에 관한 연구들이 꾸준하게 진 행되어왔지만, 이를 뒷받침 할 다양한 분자적 수준의 기전에 대한 이해는 여전히 미흡한 실정이다.

최근 들어, 운동의 긍정적 효과를 설명하는데 있어 자가포

\section{*Corresponding author}

Tel : +82-2-3277-2563, Fax : +82-2-3277-2846

E-mail : jun@ewha.ac.kr

This is an Open-Access article distributed under the terms of the Creative Commons Attribution Non-Commercial License (http://creativecommons.org/licenses/by-nc/3.0) which permits unrestricted non-commercial use, distribution, and reproduction in any medium, provided the original work is properly cited. 식(autophagy)이 중요한 역할을 한다는 사실이 제시되면서 관 련된 다양한 연구들이 진행되고 있다[3,13]. 자가포식이란 자 가포식소체(autophagosome)에서 리소좀(lysosome)으로 이 어지는 경로를 통해 세포 내에서 일어나는 자가분해(self-degradation) 시스템이다[17]. 안정시에는 세포기관이나 단백질 의 정상적 기능을 유지 및 관리하는 역할을 하고, 자극에 의해 반응이 증가되면 필요 없는 단백질을 분해하는 이화작용 (catabolism)을 통해 세포가 변화된 상태에 적응할 수 있게 하 는 역할을 수행한다[14]. 자가포식은 손상된 세포소기관 (organelles)과 세포막 등을 제거하고 재활용하는 기능을 수행 하여 세포의 생존을 돕고 세포의 에너지 수요를 충족시키는데 도움을 준다[14, 15, 21]. 뿐만 아니라 자가포식은 당뇨, 암, 신 경쇠퇴증(neurodegenerative disease), 염증질환(inflammatory disease)을 예방하는 등 여러 가지 건강상의 이점을 가지고 있다[2, 22].

최근까지의 자가포식 연구는 단백질 대사, 세포사멸(apoptosis), 면역, 영양 상태, 질병, 노화 등과 관련되어 이루어져 왔고, 주로 자가포식 그 자체가 세포조직과 인체에 미치는 영 향에 초점이 맞추어져 진행되어 왔다 $[7,15,16]$. 그러나 최근 보고된 바에 의하면 운동이 자가포식을 유도하는 요인이 되 며, 운동으로 유도된 자가포식은 신체 다양한 조직에서 긍정 
적인 영향을 미친다고 보고하고 있다[3, 13]. 그러므로 운동에 의해 자가포식이 어떻게 변화하는지를 밝히고 그 기전을 밝혀 낸다면 신체 건강과 관련된 운동의 효과를 보다 구체적으로 설명할 수 있을 것이다.

인간을 대상으로 운동에 의한 골격근의 자가포식을 조사한 연구에 따르면 일회성의 최대 지구성 운동(ultra-endurance exercise)을 수행했을 때 자가포식 관련 유전자인 ATG4b, ATG12, Gabarapl1, LC3b, Cathepsin L, BNIP3가 증가하였고 [9], LC3bП, ATG5와 결합된 ATG12 (ATG12 conjugated ATG5)가 증가했음을 보고하였다[10]. 또 다른 연구에서 쥐를 대상으로 30 분간 일회성 운동을 실시한 뒤 심장근에서 LC3ㅍ 의 증가를 보고하였지만, 운동 직후에는 감소하였고 운동 1 시 간 이후에는 증가하는 경향을 보였음을 제시하였다[18]. 쥐를 대상으로 110 분간 일회성 운동을 실시한 또 다른 연구에서도 골격근과 심장근 모두에서 LC3가 증가했음을 보고하고 있다 [6]. 또한 운동으로 유도된 자가포식이 근육의 글루코스 항상 성(glucose homeostasis)과 지질(lipid) 대사 개선에 영향을 미 치며, 그 과정에서 자가포식 관련 유전자 BCL2가 중요한 역할 을 한다고 보고하였다.

한편, 대조적으로 운동에 의해 자가포식이 감소한다는 연구 결과도 보고되어 있다. 쥐를 대상으로 50 분간 일회성 운동을 실시한 다음 운동 직후, 3 시간 후, 6 시간 후, 12 시간 후의 골격 근의 자가포식의 변화를 분석한 연구 결과에 따르면, 모든 시 간대에서 LC3가 유의하게 감소하였고, Beclin1과 Atg7, Atg5와 결합된 형태의 Atg12의 단백질 발현이 모든 시간대에 서 유의하게 감소하였다. 또한 LAMP2a의 발현도 운동 직후를 제외한 모든 시간대에서 유의하게 감소하였다[11]. 이와 같이 현재까지 진행된 연구들은 다양한 결과들을 보고하고 있고, 보고된 연구들 모두 일회성 운동에 의한 자가포식만을 제시하 고 있다.

신체는 운동에 따라 다양한 대사적 변화를 나타내며, 운동 의 형태가 일회성 운동인지 아니면 만성적 운동인지에 따라 상이하게 반응하고 적응하는 특성을 가지고 있다. 일회성 운 동은 순간적이고 일시적인 대사 반응을 이끌어내지만 장기간 의 만성적 운동은 대사적 적응을 유발한다[20]. 일반적으로 일 회성 운동에 따른 대사적 변화는 당 수송(glucose transport)과 인슐린 활동을 통한 글루코스 항상성의 유지와 관련이 있는 것으로 알려져 있고[1], 만성적인 운동은 미토콘드리아 숫자의 증가, GLUT4 단백질 발현의 증가, 지질수준의 변화를 유도하 는 것으로 알려져 있다 $[4,8]$. 운동의 형태에 따라 신체 대사와 분자적 기전은 상이하게 나타나기 때문에 운동에 의한 자가포 식을 연구하는데 있어 일회성 운동에 의한 변화뿐만 아니라 장기간의 만성적인 운동에 따른 변화를 연구할 필요성이 있 다. 또한 신체의 대사적 반응 및 적응은 운동 지속시간에 따라 서도 상이하게 나타나기 때문에 지속시간에 따른 자가포식 변화에 대해서도 연구할 필요가 있다.
신체는 운동 자극이 일회성인지 혹은 만성적인지에 따라 반응과 적응이 상이하게 나타나기 때문에 운동으로 유도되는 자가포식을 연구하는데 있어서도 일회성 운동과 만성적 운동 을 구분하여 조사할 필요가 있다. 하지만 현재까지 만성적 운 동이 자가포식에 미치는 영향에 대한 연구는 보고된 것이 없 으며, 또한 건강상의 이점과 관련된 운동의 효과를 설명하는 데 있어 유산소운동을 빼 놓을 수 없음에도 불구하고 만성적 으로 지속되는 유산소운동이 자가포식에 미치는 영향에 대한 연구는 전무하다. 따라서 본 연구는 자가포식 관련 유전자의 발현에 있어 일회성 및 만성적 유산소운동이 차별적으로 영향 을 미친다는 것을 조사하여 운동의 효과를 설명하는 기전을 찾는데 그 목적이 있다.

\section{재료 및 방법}

\section{실험대상}

실험에 사용한 초파리는 White-eyed mutant Drosophila melanogaster $\left(W^{1118}\right)$ 이다. 암컷과 수컷 약 200 마리를 분양 받아 교배를 시킨 후 세대가 같도록 만들어 실험에 사용하였다. 초 파리는 온도 $25^{\circ} \mathrm{C}$, 습도 $50 \%, 12$ 시간 낮/밤 주기를 유지하는 초파리 방에서 키웠고, $10 \%$ yeast, $10 \%$ sucrose, $2.5 \%$ agar가 포함된 기본 배지를 사용하였다.

\section{실험설계}

세대가 같고 동일한 조건에서 키워진 초파리들을 태어난 지 3 일째 되는 날 암수 구분을 하여 암컷만 따로 분리하였고, 분리한 암컷을 한 시험관(vial)에 25 마리씩, 총 18 개로 나누어 넣었다. 집단은 실험군(exercise, $\mathrm{EX}$ )과 통제군(control, $\mathrm{CON}$ ) 두 집단으로 나누어 각 집단에 3 개의 시험관을 배정하였다. 일회성 운동그룹은 태어난 지 10 일째 되는 날 하루 운동을 시행하였고, 만성적 운동그룹은 태어난 지 4 일째 되는 날부터 일주일 간 운동을 시행하였다.

운동은 중력의 반대 방향으로 이동하는 초파리의 특성을 이용하여 제작된 운동기구(Power Tower)를 사용하여 실시하 였다(Fig. 1). 운동을 할 때 실험집단과 통제집단이 운동기구로 부터의 자극을 동일하게 받을 수 있도록 두 집단 모두를 운동 기구에 장착하였고, 통제집단의 경우에는 시험관 전용 솜을 바닥과 $5 \mathrm{~mm}$ 간격을 두고 끼워 넣어 운동을 하지 못하도록

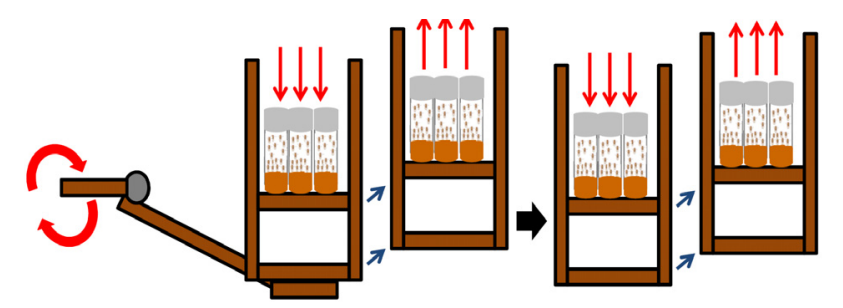

Fig. 1. Schematic representation of the Power Tower. 
통제하였다[19]. 그리고 운동이 끝난 후에는 끼워 넣었던 솜을 다시 원상복귀 하여 실험집단과 동일한 조건을 만들어 주었다.

\section{운동 프로토콜}

일회성 운동그룹은 단 하루 3 시간 운동을 실시하였고, 만성 적 운동그룹은 일주일 간 매일 하루에 한 번 2시간, 3 시간 두 그룹으로 나누어 실시하였으며, 운동 횟수는 1 분에 4.5 회로 정하여 실시하였다.

\section{초파리 분쇄}

실험군과 통제군 모두 운동이 끝난 직후 몸통 전체를 분쇄 하였다. 이산화탄소를 사용하여 초파리를 마취시킨 다음 각 시험관에서 25마리씩을 분리해 $1 \mathrm{ml}$ 의 Trizol reagent (Invitrogen, Japan)에 넣고 분쇄하였다. 분쇄 후 다음 분석 시까지 $-70^{\circ} \mathrm{C}$ 냉동기에 보관하였다.

\section{$\mathrm{RNA}$ 추출 및 $\mathrm{cDNA}$ 합성}

Trizol에 분쇄된 초파리 몸통 조직과 chloroform의 비율이 5:1이 될 수 있도록 chloroform $200 \mu 1$ 를 넣고, 10 15초간 혼합 해 주었다. 상온에서 2 분간 반응시킨 후 $4^{\circ} \mathrm{C}$ 에서 $13,000 \mathrm{rpm}$ 으 로 15 분간 원심분리를 하였다. 상층액 $150 \mu 1$ 를 취해 isopropyl alcohol $150 \mu 1$ 를 넣은 다음 $4^{\circ} \mathrm{C}$ 에서 $12,000 \mathrm{rpm}$ 으로 10 분간 원심분리 하였다. 생성된 pellet을 제외한 상층액을 버리고 $\mathrm{DEPC}$ 로 희석한 $70 \%$ 에탄올 $1 \mathrm{ml}$ 를 넣은 후 $4^{\circ} \mathrm{C}$ 에서 12,000 $\mathrm{rmp}$ 으로 5 분간 원심분리를 하였다. Pellet을 건조시킨 후 $\mathrm{DEPC}$ water $100 \mu 1$ 로 용해시킨 뒤, $65^{\circ} \mathrm{C}$ 에서 15 분간 heat inactivation을 시키고, UV 흡광도 $260 \mathrm{~nm}$ 에서 RNA 농도를
측정하였다. $1 \mu \mathrm{g} / \mu \mathrm{l}$ 의 RNA를 $5 \mathrm{X}$ reverse-transcriptase reaction buffer, $2.5 \mathrm{mM}$ dNTP, random primer, RNase inhibitor, M-MLV reverse-transcriptase를 함유한 cDNA master mix (Invitrogen Life Technologies, Carlsbad, CA)와 혼합 하여 $25^{\circ} \mathrm{C}$ 에서 10 분, $42^{\circ} \mathrm{C}$ 에서 60 분, 그리고 $95^{\circ} \mathrm{C}$ 에서 5 분간 $\mathrm{PCR}$ 을 이용해 $\mathrm{cDNA}$ 를 합성하였다.

\section{정량 실시간 연쇄반응(Real-time quantitative PCR)}

Atg1, Atg6, Atg8a의 mRNA 발현량을 측정하기 위해 SYBR FAST qPCR Kit (Applied Biosystems, USA)와 Applied Biosystems 7300 기기를 사용하여 정량 실시간 연쇄반응을 실 시하였다. 측정값의 신뢰도를 확보하기 위해 모든 샘플을 2회 반복 측정 하였고, $\operatorname{target}$ genes (Atg1, Atg6, Atg8a)의 mRNA 발현량은 RP49 (ribosomal protein 49)의 발현량을 기준으로 보정하였다. 실험에 사용된 primer는 COSMO사에서 제작하 였으며 각 유전자의 primer sequence는 Table 1에 제시하였다.

\section{자료처리}

운동에 따른 자가포식 관련 유전자의 mRNA 발현량에 유 의한 차이가 있는지를 검증하기 위해서 Window용 SPSS 18.0 프로그램을 이용하여 독립표본 t-검정을 실시하였다 $(p<0.05)$.

\section{결 과}

일회성 유산소운동이 자가포식 유전자인 Atg1, Atg6, Atg8a의 mRNA 발현에 미치는 영향을 알아보기 위해 정량 실시간 연쇄반응을 실시하였으며, 그 결과는 다음과 같다. Fig. 2

Table 1. Primer sequences for real-time PCR

\begin{tabular}{|c|c|c|}
\hline Gene & Forward primer & Reverse primer \\
\hline Atg1 & 5'-CAATGGCAGCGGACTATTGC-3' & 5'-AATTATGGTTGCCGCAAGGG-3' \\
\hline Atg6 & 5'-TGCGCCATTTTTCCACACTC-3' & 5’-CATGGAGTCGGCACACTCTT-3’ \\
\hline Atg8a & 5'-TTCCACCAACATCGGCTACC-3' & 5’-GTGGCATTTCCTGCGGTTTT-3’ \\
\hline RP49 & 5'-AGATCGTGAAGAAGCGCACCAAG-3’ & 5'-CACCAGGAACTTCTTGAATCCGG-3' \\
\hline
\end{tabular}
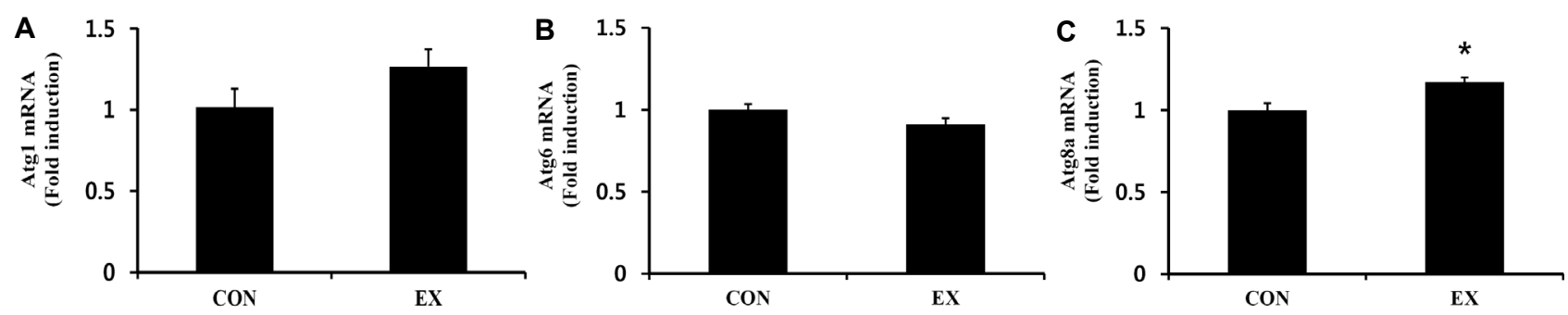

Fig. 2. The effect of acute aerobic exercise on Atg1, Atg6, and Atg8a mRNA expression. A. Atg1 mRNA expression showed a tendency to elevate but there is no significant difference. B. No significant change was observed in Atg6 mRNA expression. C. Atg8a mRNA expression was increased by $17 \%$. Target mRNA values are shown normalized to the RP49 mRNA level for each sample. Samples were analyzed in duplicate in parallel with RP49. Significantly different from the control group $(p<0.05)$. Values are means \pm SE. 
에 제시된 바와 같이 3 시간의 일회성 운동을 실시한 집단과 운동을 하지 않은 집단을 비교하였을 때 운동을 실시한 집단 의 $\operatorname{Atg} 1 \mathrm{mRNA}$ 발현이 증가하는 경향이 나타났으나 통계적 으로는 유의하지 않았고(Fig. 2A), Atg6 mRNA 발현에도 집단 간의 유의한 차이가 없었다(Fig. 2B). 반면 일회성 운동에 의해 Atg8a mRNA 발현이 $17 \%(p<0.05)$ 유의하게 증가한 것이 나 타났다(Fig. 2C).

만성적 유산소운동이 자가포식에 미치는 영향을 알아보기 위해 일주일간 하루 2시간씩 운동을 실시한 후 Atg1, Atg6, Atg8a의 mRNA 발현을 측정한 결과 Atg1 mRNA 발현에는 유의한 차이가 없었고(Fig. 3A), 마찬가지로 Atg8a mRNA 발 현에도 유의한 차이가 없었다(Fig. 3C). 그러나 2시간의 만성 적 운동에 의해 $\operatorname{Atg} 6 \mathrm{mRNA}$ 발현이 $29 \%(p<0.05)$ 유의하게 증가한 것이 나타났다(Fig. $3 \mathrm{~B})$. 운동시간을 늘려 일주일간 하 루 3시간씩 만성적 운동을 실시하였을 때 운동을 실시한 집단 의 $\operatorname{Atg} 1, \operatorname{Atg} 6, \operatorname{Atg} 8 \mathrm{a}$ mRNA 발현이 모두 유의하게 증가한 것으로 나타났다. Atg1 mRNA 발현이 57\% $(p<0.05)$ 유의하게 증가하였고(Fig. 4A), Atg6 mRNA 발현은 37\% $(p<0.05)$ 증가 하였으며(Fig. 4B), Atg8a mRNA 발현은 71\% $(p<0.05)$ 유의하 게 증가하였다(Fig. 4C).

\section{고 찰}

자가포식이란 세포 내부 물질이 세포 스스로에 의해 분해되
어 없어지는 작용으로 효모에서부터 포유류까지 모든 진핵생 물에게서 나타나는 것으로 알려져 있다[7, 13]. 세포 내 세포질 에 이중막으로 둘러싸여 있는 소포(vesicle)인 자가포식소체가 손상된 세포소기관이나 단백질을 에워싸서 구체를 형성하면 이렇게 형성된 구형의 자가포식소체는 리소좀으로 이동하게 되고, 자가포식소체의 외부막이 리소좀과 융합하면서 내부에 있던 소포와 함께 손상된 세포소기관과 단백질이 리소좀의 단백질 분해효소(protease)에 의해 분해된다[7]. 분해된 물질 들은 영양분 결핍, 에너지 고갈 등의 스트레스가 가해지는 상 태 하에서 재활용되어 세포 생존에 필요한 에너지를 만들거나 또 다른 새로운 세포소기관을 만들어내는데 사용된다[23].

과학 분야에서 자가포식에 대한 연구가 시작된 지는 그리 오래되지 않았다. 1950년대 초반 이후부터 자가포식소체에 대 한 연구가 진행되긴 했지만[12], 자가포식이 연구되고 그 기전 이 알려지기 시작한 것은 10 년이 조금 더 되었을 뿐이다[7]. 자가포식 기전에 관여하는 유전자는 ATG (autophagy-related gene)라고 불리는데 현재까지 31개의 ATG가 발견되었다. 이 ATG 단백질은 자가포식의 단계별 과정에서 그 기능을 수행하 고 자가포식이 확장되어 퍼져나갈 수 있도록 하는 역할을 수 행한다[7]. 자가포식의 과정은 유도(induction), 자가포식소체 의 형성, 소포의 융합 및 자가포식소체의 분해 단계로 구분할 수 있다.

Atg1은 초파리에서 자가포식소체의 유도과정에 관여하는 유전자로 포유류에서는 ULK1, ULK2가 Atg1의 동형체에 해
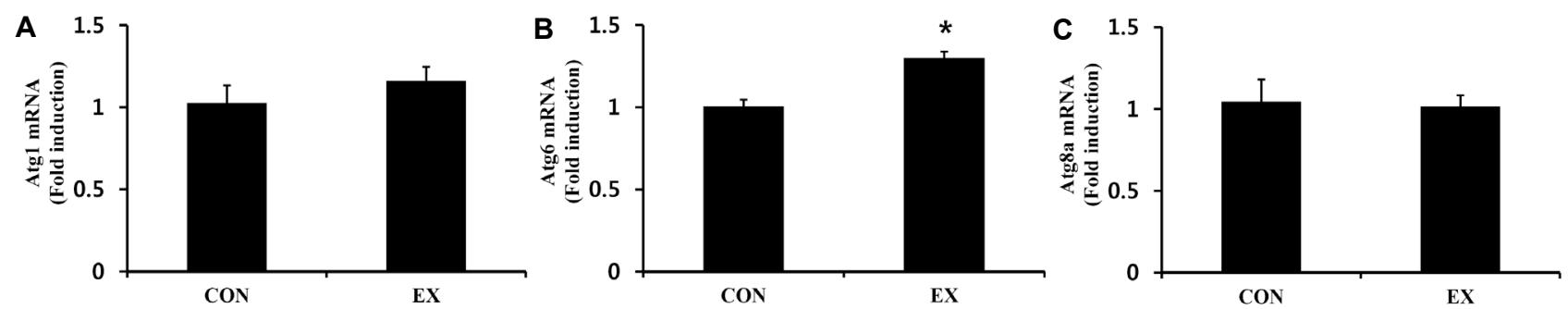

Fig. 3. The effect of chronic aerobic exercise (2 hr) on Atg1, Atg6, and Atg8a mRNA expression. A. No significant increase was observed in Atg1 mRNA expression. B. Atg6 mRNA expression was increased by 29\%. C. No significant change was observed in Atg8a mRNA expression. Samples were analyzed in duplicate in parallel with RP49. Significantly different from the control group $(p<0.05)$. Values are means $\pm \mathrm{SE}$.
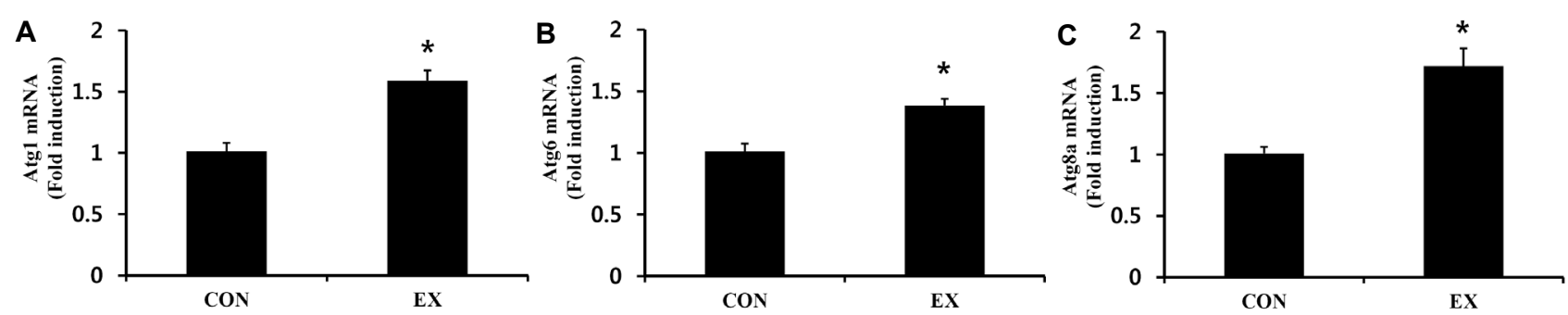

Fig. 4. The effect of chronic aerobic exercise (3 hr) on Atg1, Atg6, and Atg8a mRNA expression. A. Atg1 mRNA expression was increased by $57 \%$. B. Atg6 mRNA expression was increased by 37\%. C. Atg8a mRNA expression was increased by $71 \%$. Samples were analyzed in duplicate in parallel with RP49. Significantly different from the control group $(p<0.05)$. Values are means $\pm \mathrm{SE}$. 
당한다[24]. Atg1은 자가포식을 유도하는데 필수적인 요소로 써, 활성이 증가하면 $\operatorname{Atg} 13$ 과 $\operatorname{Atg} 17$ 에 결합하는 친화력이 증 가하여 Atg1-Atg13-Atg17의 형성을 증가시키고, 자가포식소 체의 형성을 유도하는데 관여하는 다양한 Atg 단백질들을 동 원하는 역할을 하는 것으로 알려져 있다. 선행연구에서는 일 회성 운동을 실시했을 때 ULK2의 mRNA 발현에 변화가 없음 을 보고하고 있는데[9], 본 연구에서도 선행연구와 마찬가지로 일회성 운동에 의한 Atg1 mRNA발현에 유의미한 변화가 없 음을 확인하였고, 하루 2시간씩 일주일 간 지속되는 만성적 운동을 실시했을 때도 유의미한 변화가 나타나지 않았다. 반 면 3시간씩 운동을 수행한 경우에는 Atg1 mRNA 발현이 유의 하게 증가된 것이 나타났다. 본 연구에서 만성적 운동과 함께 3시간의 일회성 운동을 실시한 이유는 일회성 운동에 의한 자가포식 반응을 측정 할 뿐만 아니라, 만성적으로 운동을 시 켰을 때 증가하는 자가포식이 정말 만성적인 운동에 의한 결 과인지 아니면 단지 마지막 날 실시한 운동 자극에 의한 변화 인지를 확인하기 위함이었다. 일회성 운동에 의해서는 Atg1 mRNA 발현이 증가하지 않고 만성적인 운동에 의해서 발현이 증가하였다는 결과를 통해 Atg1 mRNA 발현 증가가 지속된 운동에 의해 유도된 것으로 판단된다. 그리고 2시간 트레이닝 에 의해서는 변화하지 않고 3시간 트레이닝에 의해서만 발현 이 증가된 것을 통해 Atg1 유전자는 운동의 자극빈도뿐만 아 니라 지속시간에 의해서도 영향을 받는 것으로 사료된다.

Atg6는 초파리에서 자가포식소체를 형성하는 과정 중 핵생 성(nucleation) 단계에 관여하는 유전자로 포유류에서는 Beclin1 (BECN1)에 해당한다[24]. Atg6 (Beclin1 또는 BECN1) 는 buffy (BCL2 또는 Bcl-2)에 의해서 조절되는데, 영양분이 풍부한 상태에서 buffy는 Atg6과 결합하여 자가포식을 억제 하는 역할을 한다. 반면에 스트레스 자극을 받으면 결합되어 있던 Atg6과 buffy가 분리되면서 자가포식에 관여하는 것으 로 알려져 있다. 선행연구에 따르면 일회성의 최대 지구력 운 동을 수행했을 때 Beclin2 mRNA 발현에는 변화가 없었거나 [9], 증가하는 경향이 나타났지만 유의하지 않았다는 결과가 보고되어 있다[10]. 또한 그와는 대조적인 결과도 보고되었는 데, 50 분간 일회성 운동을 실시한 다음 운동 직후, 3 시간 후, 6시간 후, 12시간 후 Beclin1 단백질의 발현을 본 결과 모든 시간대에서 발현이 유의하게 감소하였다[11]. 본 연구에서는 일회성 운동에 의한 Atg6 mRNA 발현에 변화가 없었고, 만성 적 운동에 의해서는 2 시간, 3 시간 그룹 모두에서 유의한 증가 가 나타났다. 이 결과를 통해 Atg6는 규칙적으로 지속된 만성 적 운동에 의해서만 발현이 증가될 것으로 사료된다. 또한, Atg1과 달리 하루 2시간씩 운동을 수행했을 때도 3시간과 큰 차이 없이(29\% vs. $37 \%)$ 발현이 증가했음을 통해 Atg6는 Atg1 보다 상대적으로 더 민감하게 만성적인 운동자극에 반응하는 것으로 사료된다.

자가포식소체의 핵 형성 단계 이후에는 자가포식소체의 막
이 늘어나고 확장되는 과정이 일어나는데 이 과정을 신장 (elongation) 및 확장(expansion) 단계라고 한다. Atg8은 Atg7 에 의해 활성화되어 Atg3로 이동한 다음 Phosphatidylethanolamine $(\mathrm{PE})$ 와 결합하여 Atg8-PE를 동원하는 것으로 알려 져 있다. 그리고 신장 및 확장 단계 이후 자가포식소체의 형성 이 완성되면 Atg4에 의해 PE로부터 분리되어 세포질로 다시 들어가는 것으로 알려져 있다. Atg8은 자가포식소체의 크기를 조절하는 역할을 수행하는 유전자로도 알려져 있으며, 초파리 에서의 $\operatorname{Atg} 8$ 과 포유류에서 $\mathrm{Atg} 8$ 의 동형체인 LC3는 자가포식 이 유도되었음을 알 수 있는 표식 유전자로(marker genes) 현 재 널리 사용되고 있다[24]. 선행연구에 따르면 일회성 최대 지구력 운동에 의해 Atg8의 상동체(homologue)인 Gabarapl1 과 LC3b의 mRNA 발현이 유의하게 증가하였고[9], LC3픠 의 단백질 발현도 유의하게 증가하였음이 보고되었다[10]. 심장 근에서도 단발성 운동에 의해 LC3피랄현이 유의하게 증가한 것이 나타났지만, 이는 운동 직후가 아닌 1시간 후에 나타난 결과라고 보고되어 있다[18]. BCL2 유전자를 조작하여 자가포 식에 결함을 갖고 있는 쥐 $(\mathrm{BCL} \mathrm{AAA})$ 를 대상으로 일회성으로 운동을 실시하여 LC3의 변화를 본 연구에서는 정상 쥐의 경우 골격근과 심장근에서 $\mathrm{LC} 3$ 가 증가하였지만 $\mathrm{BCL} 2 \mathrm{AAA}$ 쥐의 경우 운동으로 유도된 자가포식이 확연히 악화되었고 LC3의 증가가 통제군 보다 훨씬 적게 나타난 것이 보고되었다[6]. 대 조적으로 한 연구에서는 일회성 운동에 의해 LC3피단백질 발현이 유의하게 감소하였다고 보고하고 있지만[11], 그 외의 대부분의 선행연구에서는 일회성 운동에 의해 $\operatorname{Atg} 8$ (LC3, LC3b, LC3 I, Gabarapl1)이 유의하게 증가했음을 보고하고 있다. 선행연구와 마찬가지로 본 연구에서도 3 시간 일회성 운 동에 의해 Atg8a mRNA 발현이 유의하게 증가하였고, 만성적 인 운동에 의해서도 발현이 매우 유의하게 증가하였다. 그러 나 만성적 운동의 경우 3시간씩 운동을 수행한 그룹에서만 유의하게 증가한 것을 미루어볼 때, 일정시간 이상의 충분한 운동 자극이 주어져야만 Atg8a의 발현이 크게 증가하는 것으 로 사료된다. 또한 Atg8a mRNA 발현이 3시간의 만성적 운동 뿐만 아니라 일회성 운동에 의해서도 유의하게 증가하였음을 통해 Atg8이 자가포식의 표식 유전자로 널리 알려져 있는 만 큼 일시적으로 주어지는 자극에도 민감하게 반응하여 유의한 증가를 보인 것이라 사료된다.

본 연구에서 나타나는 제한점 및 제언은 다음과 같다. 첫째, 실험집단의 초파리가 운동을 하면서 배지에 있는 영양분을 섭취했는지 아닌지를 확인하지 못하였다. 만약 영양분을 섭취 했다면 Atg 유전자들의 mRNA 발현 수준이 오직 운동에 의해 서 증가하는 수준보다 더 낮게 나타났을 가능성이 있다. 왜냐 하면 영양분이 충분한 상태에서 자가포식은 거의 나타나지 않는다고 보고되어 있기 때문이다[24]. 운동 중 섭취하는 영양 분이 운동으로 유도된 자가포식을 낮추었을 가능성을 배제할 수 없으므로 이후 연구에서는 초파리가 운동 중 영양분을 섭 
취하는지 아닌지를 함께 확인하여 자가포식에 미치는 영향을 논할 필요가 있을 것이다. 둘째, 포유류와는 다른 초파리의 특성상 장기간 운동을 하는 동안 개개의 초파리가 일정하게 운동을 하는지 아닌지를 일일이 확인하지는 못하였다. 그러나 본 연구에서의 운동시간과 운동횟수는 Piazza et al. [19]의 연 구에 의거한 것이므로 어느 정도 일정하게, 꾸준히 운동을 했 다고 가정할 수가 있을 것이다. 추후 연구를 통해 초파리 운동 에 더 적합한 운동 프로토콜을 제시할 필요가 있을 것으로 사료된다. 셋째, 초파리의 몸통은 사람의 간에 해당하는 조직 으로 초파리 몸통에서의 자가포식 변화가 특정 조직의 자가포 식 변화를 직접적으로 설명할 수 있다고 단언하기는 힘들다. 그러나 인간과 유전적으로 높은 상동성을 띠고 있는 초파리의 대사적 변화를 봄으로써 운동에 의한 신체의 전반적인 대사 변화를 추론할 수 있기 때문에 운동으로 유도되는 자가포식을 연구하는데 무리가 없을 것이라 사료된다.

자가포식은 손상된 세포소기관과 단백질, 세포막을 제거하 고 재활용하는 기능을 수행하여 세포의 생존을 돕고 세포의 에너지 수요를 충족시키는데 도움을 줄 뿐만 아니라, 당뇨, 암, 신경 쇠퇴증을 예방하는 등 여러 가지 건강상의 이점을 가지고 있다. 운동에 의해 자가포식이 증가한다는 것을 밝히 고 그 기전을 알아낸다면 대사, 질병, 노화 등과 관련된 운동의 효과를 보다 더 구체적으로 설명할 수 있음은 분명하다. 그러 나 이제까지의 운동과 자가포식을 연구한 선행연구들은 일회 성 운동에 의한 자가포식만을 조사하였고, 일회성 운동과 만 성적 운동에 의한 자가포식을 조사한 연구는 보고된 것이 없 다. 그러므로 본 연구는 초파리에서의 자가포식 관련 유전자 가 일회성 운동과 만성적 운동에 의해 차별적으로 증가한다는 것을 밝히고, 만성적 유산소운동에 의해서 자가포식이 증가한 다는 것을 밝혔음에 중요한 의의가 있다.

\section{References}

1. Defronzo, R. A., Ferrannini, E., Sato, Y. and Felig, P. 1981. Synergistic interaction between exercise and insulin on peripheral glucose uptake. J Clin Invest 68, 1468-1474.

2. Ebato, C., Uchida, T., Arakawa, M., Komatsu, M., Ueno, T., Komiya, K., Azuma, K., Hirose, T., Tanaka, K., Kominami, E., Kawamori, R., Fujitani, Y. and Watada, H. 2008. Autophagy is important in islet homeostasis and compensatory increase of $\beta$ cell mass in response to high-fat diet. Cell Metab 8, 325-332.

3. Garber, K. 2012. Autophagy. Explaining exercise. Science 335, 281.

4. Gollnick, P. D., Armstrong, R. B., Saubert, C. W., Piehl, K. and Saltin, B. 1972. Enzyme activity and fiber composition in skeletal muscle of untrained and trained men. J Appl Physiol 33, 312-319.

5. Handschin, C. and Spiegelman, B. M. 2008. The role of exercise and PGCla in inflammation and chronic disease.
Nature 454, 463-469.

6. He, C., Bssick, M. C., Moresi, V., Sun, K., Wei, Y., Zou, Z., An, Z., Loh, J., Fisher, J., Sun, Q., Korsmeyer, S., Packer, M., May, H. I., Hill, J. A., Virgin, H. W., Gilpin, C., Xiao, G., Duby, R. B., Scherer, P. E. and Levine, B. 2012. Exercise-induced BCL2-regulated autophagy is required for muscle glucose homeostasis. Nature 481, 511-517.

7. He, C. and Klionsky, D. J. 2009. Regulation mechanisms and signaling pathways of autophagy. Annu Rev Genet 43, 67-93.

8. Holloszy, J. O. 1967. Biochemical adaptations in muscle: effects of exercise on mitochondrial oxygen uptake and respiratory activity in skeletal muscle. J Biol Chem 242, 2278-2282.

9. Jamart, C., Benoit, N., Raymackers, J. M., Kim, H. J., Kim, C. K. and Francaux, M. 2012. Autophagy-related and autophagy-regulatory genes are induced in human muscle after ultraendurance exercise. Eur J Appl Physiol 112, 31733177.

10. Jamart, C., Francaux, M., Millet, G. Y., Deldicque, L., Frere, D. and Feasson, L. 2012. Modulation of autophagy and ubiquitin-proteasome pathways during ultra-endurance running. J Appl Physiol 112, 1529-1537.

11. Kim, Y. A., Kim, S, Y. and Song, W. 2011. Autophagic response to a single bout of moderate exercise in murine skeletal muscle. J Physiol Biochem 68, 229-235.

12. Klionsky, D. J. 2007. Autophagy: from phenomenology to molecular understanding in less than a decade. Nat Rev Mol Cell Biol 8, 931-937.

13. Klionsky, D. J. and Saltiel, A. R. 2012. Autophagy works out. Cell Metab 15, 273-274.

14. Kuma, A. and Mizushima, N. 2010. Physiological role of autophagy as an intracellular recycling system.: with an emphasis on nutrient metabolism. Semin Cell Dev Biol 21, 683-690.

15. Levine, B. 2007. Autophagy and cancer. Nature 446, 745-747.

16. Levine, B., Mizushima, N. and Virgin, H. W. 2011. Autophagy in immunity and inflammation. Nature 469, 323-335.

17. Mizushima, N. and Levine, B. 2010. Autophagy in mammalian development and differentiation. Nat Cell Biol 12, 823-830.

18. Ogura, Y., Lemitsu, M., Naito, H., Kakigi, R., Kakehashi, C., Maeda, S. and Akema, T. 2011. Single bout of running exercise changes LC3- $\Pi$ expression in rat cardiac muscle. Biochem Biophys Res Commun 414, 756-760.

19. Piazza, N., Gosangi, B., Devilla, S., Arking, R. and Wessells, R. 2009. Exercise-training in young Drosophila melanogaster reduces age-related decline in mobility and cardiac performance. PLoS One 4, E5886.

20. Rockl, K. S. C., Witczak, C. A. and Goodyear, L. J. 2008. Signaling mechanisms in skeletal muscle: acute response and chronic adaptations to exercise. IUBMB Life 60, 145-153.

21. Sandri, M. 2010. Autophagy in health and disease. 3. Involvement of autophagy in muscle atrophy. Am J Physiol Cell Physiol 198, 1291-1297.

22. Yang, L., Li, P., Fu, S., Calay, E. S. and Hotamisligil, G. S. 2010. Defective hepatic autophagy in obesity promotes ER stress and causes insulin resistance. Cell Metab 11, 467-478. 
23. Yorimitsu, T. and Klionsky, D. J. 2005. Autophagy: molecular machinery for self-eating. Cell Death Differ 12, 15421552.
24. Zirin, J. and Perrimon, N. 2010. Drosophila as a model system to study autophagy. Semin Immunopathol 32, 363-372.

\section{초록 : 일회성 및 만성적 유산소운동이 초파리의 자가포식 관련 유전자 발현에 미치는 영향}

\section{김희연 · 김혜진 · 황지선 · 이원준*}

(이화여자대학교 건강과학대학 체육과학과)

자가포식은 자가포식소체에서 리소좀으로 이어지는 경로를 통해 세포내에서 일어나는 자가분해 시스템으로 다 양한 질병과 관련된 운동의 효과를 설명하는데 있어 중요한 역할을 하는 것으로 알려져 있다. 하지만 현재까지 보고된 대부분의 연구는 일회성 운동 혹은 저항성 운동에 의한 자가포식만을 조사한 것으로 일회성 운동과 만성 적 운동을 함께 조사한 연구는 전무하다. 따라서 본 연구의 목적은 일회성 및 만성적 유산소운동이 자가포식에 미치는 영향을 알아보는 것이다. White-eyed mutant Drosophila melanogaster를 대상으로 하여 이들을 통제집단, 일회성 운동 집단, 일주일간 하루 2 시간 또는 3 시간씩 운동을 실시한 집단에 무선배정 하였고, 운동은 일회성 운 동과 만성적 운동으로 구성하여 실시하였다. 정량 실시간 연쇄반응을 통해 Atg1, Atg6, Atg8a 유전자의 발현을 관찰한 결과 일회성 운동은 Atg8a mRNA 발현을 유의하게 증가시켰다. 그러나 Atg1, Atg6 mRNA 발현은 일회성 운동으로 유도되지 않았다. 또한 2시간의 만성적 운동에 의해서 Atg6 mRNA 발현이 유의하게 증가되었으나 Atg1, Atg8a mRNA 발현에는 유의한 변화가 나타나지 않았다. 반면 3시간의 만성적 운동을 실시한 결과 Atg1, Atg6, Atg8a mRNA 발현이 각각 $57 \%, 37 \%, 71 \%$ 로 모두 유의하게 증가된 것을 관찰할 수 있었다. 본 연구의 결과 를 통해서 일회성의 운동은 선별된 자가포식 관련 유전자를 모두 활성화시키지는 못하지만 선택적으로 유도한다 는 사실을 확인할 수 있었고, 만성적 운동은 자가포식 관련 유전자의 발현을 증가시킨다는 사실을 확인할 수 있었 다. 따라서 본 연구는 일회성 및 만성적 유산소운동이 자가포식에 미치는 영향을 규명하였으며, 자가포식 관련 유전자가 일회성 운동과 만성적 운동에 의해 차별적으로 증가한다는 사실을 확인하였다는데 의의가 있다. 향후 운동에 의한 자가포식 연구에 있어 운동 형태 및 지속시간 등을 고려한 보다 세부적이고 체계적인 연구가 수행될 필요가 있을 것이라 사료되는 바이다. 